\title{
Meetings
}

THE COASTLINE OF CANADA, HALIFAX, NOVA SCOTIA

$$
\text { MAY Z-3, } 2978
$$

This is a conference on the coastiine of Canada dealing with littoral processes and shore morphology. It will be held at the Hotel Nova Scotian in Halifax and will be preceded by a field excursion to Minas Basin, Bay of Fundy. Several keynote speakers have been contacted, who will lead off six technical paper sessions. The technical program is given below, and illustrates the wide range of subjects and authorship, as well as the paxticipating centres in this field of study.

\section{COASTAL CONFERENCE PROGRAM}

Monday, May, 1, 1978

Introductory Remarks,

J.O. WHEELER, Deputy Director-General, Geological Survey of Canada, Ottawa

Keynote Lecture

Dr. P.D. KOMAR

SESSION 1

Chairperson: S.B. McCANN, Geological Survey of Canada, Bedford Institute of Oceanography, Dartmouth, Nova Scotia.

Wave and current forces in a mobile sand bar system. D. HUNTLEY, Dalhousie University, Halifax, Nova Scotia.

Simple models of nearshore sedimentation. A.J. BOWEN, Dalhousie University, Halifax, Nova Scotia.

Depth of disturbance in sediments and patterns of scour and aggradation under storm waves and currents in a barred nearshore environment. B. GREENWOOD and P.B. HALE, University of Toronto, Toronto, Ontario.

Sable Island sand waves and related shore processes. A. RUFFMAN, L. MEAGHER, and J.M. STEWART, Geomarine Associates Ltd., Halifax, Nova Scotia.

Storm wave climatology: A study of the magnitude and frequency of geomorphic processes. P.B. HALE and $B$. GREENWOOD, University of Toronto, Toronto, Ontario.

Some comparisons between barrier beaches of Prince Edward Island, Newfoundland and eastern United States. P.F. GODFREY and A. SNOW, University of Massachussetts, Amherst, Ma.

\section{SESSION 2}

Chairperson: G.V. MIDDLETON, MCMaster University, Hamilton, Ontario.

Changeability in small flood tidal deltas and its effects, the Malpeque Barrier System, Prince Edward Island. J.W. ARMON, McMaster University, Hamilton, Ontario.
Variations in tidal-inlet morphology and stability, eastern New Brunswick. G.E. REINSON, Geological Survey of Canada, Bedford Institute of Oceanography, Dartmouth, Nova Scotia.

Animal-sediment relationships in the upper reaches of the Bay of Fundy. M.J. RISK, McMaster University, Hamilton, Ontario.

Tidal current flow and sand bar development in Cobequid Bay, Bay of Fundy, Nova Scotia. PETROCAN, Calgary, Alberta.

Sediment transport in the intertidal area of the Minas Basin, Nova Scotia. B.F. LONG, Geological Survey of Canada, Bedford Institute of Oceanography, Dartmouth, Nova Scotia.

Patterns of sediment accumulation in the macrotidal Avon River Estuary, Bay of Fundy. J.J. LAMBIASE, MCMaster University, Hamilton, Ontario.

The sedimentary character of the Minas Basin System, Bay of Fundy, C.I. AMOS, Geological Survey of Canada, Bedford Institute of Oceanography, Dartmouth, Nova Scotia.

Discussion and Summation.

Tuesday, May 2, 1978

Keynote Lecture

Dr. J.O. NORRMAN

SESSION 3

Chairperson: D.E. BUCKLEY, Atlantic Geoscience Centre, Geological Survey of Canada, Bedford Institute of Oceanography, Dartmouth, Nova Scotia.

Beach sediment budgets and Holocene sea level changes: Nova Scotia and Labrador, D.J.W. PIPER, Dalhousie University, Halifax, Nova Scotia.

Recent morphological changes in an estuary along the Eastern Shore of Nova Scotia and their relationship with relative sea level rise, D.B. SCOTT, Dalhousie University, Halifax, Nova Scotia.

The morphometry of shore platforms with special reference to the Gaspe coast. A. TRENHAILE, University of Windsor, Windsor, Ontario.

Geomorphologie du littoral de la cote-Nord du Saint-Laurent, J.M. DUBOIS, Universite de Sherbrooke, Sherbrooke, Quebec.

The physical characteristics of southeastern Baffin Island and northern Labrador-Ungava coastline. G.H. MILLER, W.W. LOCKE and C.E. LOCKE, University of Colorado, Boulder, Colorado.

\section{SESSION 4}

Chairperson: C.F.M. LEWIS, Terrain Sciences Division, Geological Survey of Canada, Ottawa. 
Processes responsible for the correlation of giant boulders in the intertidal zone in Leaf Basin, Ungava. B. LAURIOL and J. GRAY, Universite de Montreal, Montreal, Quebec.

Coastal morphology of Makkovik Region, Labrador. P. ROSEN, Geological Survey of Canada, Bedford Institute of Oceanography, Dartmouth, Nova Scotia.

The eastern coast of James Bay, Quebec. J.C. DIONNE, Environment Canada, Ste-Foy, Quebec.

Hudson and James Bays: a low energy emergent coastline. I.P. MARTINI, University of Guelph, D. COWELL and G. WICKWARE, Environment Canada, Canada Centre for Inland Waters, Burlington, ontario.

Le littoral du S.E. de la Mer d'Hudson: un relief de cuesta. P. GUIMONT and C. LAVERDIERE, Societe de la developpement de la Baie James, et Universite de Montreal, Quebec.

Remote sensing for coastal studies in Canada, P.J. HOWARTH, McMaster University, Hamilton, Ontario.

Unmanned submersible probes, Arctic shore zone, S.M. BLASCO, Geological Survey of Canada, ottawa, Ontario.

Discussion and Summation.

Wednesday, May 3, 1977

SESSION 5

Chairperson: N. RUKAVINA, Hydraulics Div. Canada Centre for Inland waters, Burlington, Ontario.

Towards the geotechnical classification of the Great Lakes shoreline bluffs. R.M. QUIGLEY and A.J. ZEMAN, University of Western Ontario and Canada Centre for Inland Waters, Burlington, Ontario.

Prediction of time ayeraged patterns of potential shoreline erosion, transport and deposition in the Toronto waterfront, Lake Ontario, Canada. B. GREENWOOD and.D.G. MCGILLIVRAY, University of Toronto, Toronto, ontario.

Post glacial evolution and modern processes at Point Pelee, Lake Erie. J.P. COAKLEY, Canada Centre for Inland Waters, Burlington, Ontario.

Computer simulation of recurved spits. R.W. PACKER, and SHAFIQUAR RAHMAN, University of western Ontario, London, Ontario.

Morphology and sedimentology of multiple parallel bar systems, southern Georgian Bay, Ontario. R.G.D. DAVIDSON-ARNOTT, and G.F. PEMBER, University of Guelph, Guelph, Ontario.

The morphology and processes of the Lake Superior North Shore. B.A.M. PHILIIPG, Lakehead University, Thunder Bay, Ontario.

\section{SESSION 6}

Chairperson: E.H. OWENS, Louisiana State University, Baton Rouge, Lousiana.

Coastal sedimentology and processes of a high Arctic environment. R. McLAREN, Geological Survey of Canada, Ottawa, Ontario.

Coastal environments along the northern shore of Somerset Island, Northwest Territories. R.B. TAYLOR, Geological Survey of Canada, Ottawa, Ontario,

Deltaic processes and delta morphology, MacKenzie Delta, Northwest Territories. C.P. LEWIS, Inuvik Research Laboratory, Department of Indian and Northern Affairs, Inuvik, District of Mackenzie.

Genesis of morphologic features of the western delta front of the Fraser River, British Columbia. J.L. LUTERNAUER, Geological Survey of Canada, Victoria, British Columbia.

Morphology and littoral processes of the Pacific Coast of Canada. J. CLAGUE and B. BORNHOLD, Geological Survey of Canada, Vancouver and Victoria, British Columbia.

The status of coastal research in Canada. E.H. OWENS, Louisiana State University.

Discussion and Summation.

\section{ATLANTIC UNIVERSITIES GEOLOGICAL CONFERENCE}

This conference was held at Saint Mary's University, Halifax, and was hosted by the W.A. Bell Geology Club of St. Mary's geology department. Two major aspects of the conference were the field trips, and the presentation of the students technical papers. Abstracts available at the meeting are given below.

PETROLOGY OF CARBONIFEROUS GRANTTIC INTRUSTTONS IN THE VIANA DO CASTELO AREA, NORTHERN PORTUGAL

LUCINIO AREIAS, Fletcher Geology Club, Acadia

University, Wolfville, Nova Scotia.

The Carboniferous batholith of northern Portugal consists of a number of intermediate to felsic intrusions emplaced during the Hercynian orogeny. Intrusions near Viana do Castelo were investigated during August 1977 as part of an Honours thesis project to include studies of petrography, geochemistry and petrogenesis. The intrusions in the Viana do Castelo area are of economic importance as a result of the occurrence of such elements as Sn, W, Nb, Ta and $\mathrm{Au}$. They have also been used for many centuries as the predominant building material in northein Portugal, which is reflected in historic monuments, castles, bridges, roads, and homes. This report focuses on field relationships and preliminary results of petrologic studies of these rocks.

Nine plutons were studied and sampled. They include both the "older" and "younger" intrusions of previous workers in northern Portugal, but petrom graphic differences between the two groups axe not clear. Both consist of granodiorite, quartz monzon- 
ite, or granite with minor leucogranite. Grain size varies from fine to coarse, but medium-grained hypidiomorphic granular textures axe most common. Some granodiorites and quartz monzonites are porphyritic with euhedral phenocrysts of anorthoclase(?). Alkali feldspars are generally anorthoclase(?) or microcline and plagioclase feldspars range from albite to andesine and are typically zoned. Quartz contents are generally about 25 percent. Biotite and muscovite are common varietal minerals and appear as quartz-mica clots in many rocks. Apatite and zircon, the latter showing pleochroic halos in biotite and muscovite due to radiation damage, appear in accessory amounts.

Additional studies including detailed petrography, $x$-ray diffraction, and major and trace element geochemistry will attempt to define differences between older and younger intrusions and lead to an interpretation of petrogenesis and an assessment of economic potential.

\section{URANIUM OCCURRENCES OF NOVA SCOTIA}

MICHAEL CLARKE, St. Mary's University, Halifax

There are several types of uranium occurrences present in Nova Scotia. They are blanket type, roll type, hydrothermal veins and greisens, pegmatites, and granites.

Those that seem the most likely to become producers of ore are the roll and hydrothermal types. The roll type deposit is located in Tertiary sediments on the (east side) North Mountain. The hydrothermal one is at New Ross where uranium would be mined as a by-product to tin and molybdenum ores in the veins because uranium is only .28 percent.

Prospection for uranium is at an early stage in Nova Scotia. Areas of interest could be the peralkaline granites which usually contain uranium and the source of the uranium in the valley roll deposits. These areas could yield significant discoveries.

\section{GRAVITATIONAL INTERPRETATION AND MODELLING OF THE SOUTH MOUNTAIN BATHOLITH, SOUTHERN NOVA SCOTIA}

MARTEN DOUMA, Dalhousie University, Halifax, Nova Scotia.

Much controversy surrounds the issue of the geometry of the South Mountain Batholith in southern Nova Scotia. Gravity data released by the Department of Energy, Mines and Resources within the past year has allowed a reinterpretation and clarification of previously obscure information. This study was undertaken to define more clearly the subsurface geology of the South Mountain Batholith using the latest information. Data was interpreted on the basis of rock types observed in the field, especially with regard to their specific gravity.

A Bouguer Anomaly contour map reveals the presence of a large gravimetric low extending from Yarmouth to Sheet Harbour, a distance of nearly $300 \mathrm{~km}$. The low can be subdivided into three relatively intense gravitational depressions, two of which have been previously mapped as adamelite (quartz monzonite). Preliminary reconnaissance and sampling were carried out during the summer of 1977 in the third area, a region south-west of Kejimkujik National Park. Petrographic and gravitational analysis indicate that it, too, is adamellite.

The density contrast between the adamellite (S.G. 2.63) and the remaining areas of granodiorite (S.G. 2.68) is sufficiently large to allow specific gravity to be used as one of the variables in testing an intexpretive model of the dimensions of the batholith.

Using known or implied surface contacts, twoand three-dimensional models were tested. By altering the sub-surface geometry of the models it was possible to approximate the observed gravity with the gravity generated by the hypothetical model and thereby approach a possible shape for the batholith.

SEISMIC SURVEY OF THE PRE-GLACIAL OUTLET SAINT JOHN RIVER, SAINT JOHN, NEW BRUNSWICK

JAMES P. HAWKINS, University of New Brunswick, Fredericton, New Brunswick.

The retreat of the Pleistocene ice from southern New Brunswick 13,000 years ago left thick deposits of bouldery till throughout the Saint John region. The result of this deposition was the diversion of the Saint John River from its old, pre-glacial outlet to its present one, several miles further to the east.

Seismic refraction surveys conducted by the author while working for the seismic section of the Geological Survey of Canada during the summer of 1976 show clear evidence for the pre-glacial outlet. A deep north-south channel in the bedrock was found to start from South Bay, the present-day shore of the river, and to terminate with multiple outlets, into the Bay of Fundy.

The average observed bedrock compressional velocity is approximately 4,500 to $5,000 \mathrm{~m} / \mathrm{s}$, a velocity that agrees with the accepted values for the Precambrian argilites, quartzites, and carbonates that underlie the area. Overburden thicknesses vary from zero at the edges of the preglacial channel to over $100 \mathrm{~m}$ at its centre.

The geographical and geological evidence of surficial geology also supports this interpretation.

ZONATION OF FORM IN LOWER CAMBRIAN PATCH REEES, FORTEAU FM., SOUTHERN LABRADOR

ADELE POYNTER, Department of Geology, Memorial

University of Newfoundland, St. John's, Newfoundland.

Zonation of form of organisms is a common characteristic of both modern and ancient reefs. This study documents such a zonation for the reefbuilding archaeocyathids in Lower Cambrian patch reefs of the Forteau Formation, Southern Labrador.

Archaeocyathids appeared in the Lower Cambrian as the first skeletal reef building organisms, but enjoyed only a short existence, becoming extinct by the Middle cambrian. Their affinities to 
various plant and animal groups is a controversial topic and, as a result, archaeocyathid biology remains poorly understood.

Three archaeocyathid morphotypes were recognized in the Labrador patch reefs - a cone shape, a bowl and a branching form. Several metre-square quadrants were examined in two patch reef complexes and the occurrence, relative size, and orientation of the three forms were recorded within each quadrant. On the basis of these data, lateral variation of form in archaeocyathids was established. Bowl forms occur only at reef margins. Branching forms dominate the centre of the reef and cones dominate the marginal areas, where they are generally wider than at the reef centre.

This zonation is interpreted as a response to various environmental parameters such as reef position, distribution of food source, and sediment influx. 